\title{
DROP IN CONDUCTIVITY OF SEWAGE SLUDGE IN THE PROCESS OF AUTOTHERMAL THERMOPHILIC AEROBIC DIGESTION
}

\author{
Izabela Bartkowska' \\ 1 Department of Environmental Engineering Systems, Bialystok University of Technology, Wiejska 45A, 15-351 \\ Bialystok, Poland, e-mail: i.bartkowska@pb.edu.pl
}

Received: 2017.04 .23

Accepted: 2017.06 .01

Published: 2017.07.01

\begin{abstract}
The article presents research on the assessment of electrolytic conductivity changes of sludge during the process of its autothermal thermophilic aerobic digestion (ATAD), which takes place in a two-stage installation system, operating in a municipal sewagetreatment plant. In the years 2012-2014 sludge was studied and the results were analyzed. Thickened sludge in the intermediate tank, which was then directed to installation reactors, was examined. Conductivity was measured in each tank. In this manner collected results made it possible to follow the changes of this index at consecutive stages of the system. The results were statistically analyzed and it was determined to what degree, as a result of an objective process, the values of processed sludge conductivity would change. The conclusions from the carried-out studies and from own experiments are also presented.
\end{abstract}

Keywords: autothermal stabilization of sewage sludge; conductivity of sewage sludge; neutralization of sewage sludge; sanitation of sewage sludge; sewage sludge processing

\section{INTRODUCTION}

Domestic sewage contains not only physical impurities, but chemical ones as well. It consists of a large number of viruses, bacteria, fungi, and the eggs of helminths. Majority of these microorganisms belongs to the regular heterotrophic flora living in the human and animal digestive tract. There are also pathogenic species among them.

In the processes of mechanical and biological treatment large amounts of microorganisms are eliminated. But they are not neutralized and penetrate the formed sludge. Sewage-treatment plant generates then several kinds of wastes whose amount depends on the plant's size and the applied technological processes. The necessity of using highly-effective sewage treatment methods may cause generation of preliminary sludge, excess sludge, after chemical precipitation and dosing of external organic carbon source, necessary for carrying out the technological processes connected with the removal of nitric compounds (denitrification). The produced sludge needs be neutralized for legal, esthetic, and practical reasons. The economic and ecologic circumstances call for, if possible, the processed sludge being returned to the natural environment. It is the cheapest method of ultimate sludge neutralization. Natural utilization is possible only then, however, when it is stabilized, sanitary safe, and free of excessive concentration of heavy metals.

Sludge, before returned to the natural environment, must be properly rendered harmless. This procedure includes a decrease of its putrescibility though stabilization, liquidation of pathogenic organisms through disinfection, and reduction of its volume and mass.

This paper shows the process of autothermal thermophilic aerobic digestion (ATAD) of sludge as a method of its full sanitation and stabilization. It enables sludge to be transformed into biomass, which could be used naturally improving the balance of soil organic matter [Bartkowska and Dzienis 2006, Bartkowska 2013a]. However, 
the quality of sludge introduced into soil should be monitored, as it may interact with superficial and underground waters.

Proper sanitation of sludge is ensured by the time when it is held in a second-stage reactor in the temperature $55^{\circ} \mathrm{C}$ to $70^{\circ} \mathrm{C}$ [Augustin et al. 2007, Bartkowska and Wawrentowicz 2011]. The measure of its stabilization is the reduction of organic substances content, which is the consequence of chemical and biological changes [Wersoki and Hupka 2006, Layden 2007, Bartkowska 2015]. A measurement of the content of dry mass in sludge, especially its organic fraction, is time consuming and requires laboratory. Such examinations do not allow quick action at the time of ongoing process. Only measurements carried out directly in reactors make it possible to modify the process, making it optimized. ATAD installations employed in municipal sewage-tretament plants have been tested since 2003, adding to our knowledge of how to render sludge harmless. It made it possible to apply other, less common, measurements which improve the management of the process. One of the studied and analyzed indices was the electrolytic conductivity of sludge, which depends on the type and amount of dissociated dissolved substances of non-organic nature. The feasibility and quickness of measurements caused it to be commonly used for testing the general mineralization degree of waters and soil. Its measurement may be applied for approximate determination of ion strength, water salinity, dry residue and the content of dissolved substances. High values of conductivity may indicate impurity caused by biogenic substances, or by heavy metals. They may indicate salinity which in relation to sludge is very rarely tested. It is known however, that the older the sludge is, the less salt it contains [Merrington et al. 2003]. Great changes of conductivity may also result from work perturbation of a sewage-treatment plant.

The goal of initiated studies was to determine the direction of changes of electrolytic conductivity of sludge during the process of autothermal thermophilic digestion. Apart from cognitive aspect, the utilitarian aim was determination of the usefulness of objective parameter for assessment of the process during the work of installation at sewage-treatment plant, based on statistical analysis of the examination results. Coming up with a tool which enables simple, fast, and reliable assessment of the process efficacy may turn out a practical goal of the undertaken studies. The iden- tified goals may be achieved after doing suitable number or representative measurements of electrolytic conductivity of sludge, which then enable making expected correlations through graphical and computational methods.

\section{CHARACTERISTICS OF THE PROCESS AND ITS TECHNICAL SOLUTION}

TheATAD process is based on natural exothermic oxidation of carbon in aerobic conditions. An essential role is played by microorganisms which facilitate the decay of organic compounds present in sludge. It is a two-stage process. At the first stage complex organic compounds (proteins, carbohydrates, and lipids) undergo hydrolysis; also the cells of atrophying microorganisms undergo lysis. At the second stage oxidation is evoked by thermophylic microorganisms, which transforms the dissolved-in-water products of hydrolysis to low-energy compounds. Heat is emitted during those reactions, and the end-substances are $\mathrm{CO}_{2}$, $\mathrm{H}_{2} \mathrm{O}$, and $\mathrm{NH}_{3}$. This reaction can be illustrated by a simplified equation stemming from a hypothetical matter of organic cells $\mathrm{C}_{5} \mathrm{H}_{7} \mathrm{NO}_{2}$ representing active sludge [Wersocki and Hupka 2006, Zupančič and Roš 2008]:

$$
\begin{aligned}
& \mathrm{C}_{5} \mathrm{H}_{7} \mathrm{NO}_{2}+5 \mathrm{O}_{2} \rightarrow 5 \mathrm{CO}_{2}+2 \mathrm{H}_{2} \mathrm{O}+\mathrm{NH}_{3} \\
& + \text { energy } \\
& \mathrm{C}_{5} \mathrm{H}_{7} \mathrm{NO}_{2}+7 \mathrm{O}_{2} \rightarrow 5 \mathrm{CO}_{2}+3 \mathrm{H}_{2} \mathrm{O}+\mathrm{NO}_{3}^{-}+\mathrm{H}^{+} \\
& + \text {energy }
\end{aligned}
$$

Effective capture of the heat which is released during decay brings about high working temperature $\left(>50^{\circ} \mathrm{C}\right)$, this in turn, causes high degree of decay of organic substances, as well as elimination of pathogenic agents. This process requires preliminary thickening of sludge to over 4 per cent, which provides greater unitary content of organic substances, which should be no less than $40.0 \mathrm{~g} / \mathrm{l}$, expressed by chemical oxygen demand (COD) [Bartkowska et al. 2005a, 2005b].

Feeding substrates of proper thickness, with satisfactory amount of oxygen, in thermically insulated tanks, the sludge may spontaneously warm up to $55 \div 80{ }^{\circ} \mathrm{C}$ [Zhou et al. 2002, Kelly 2006, Layden 2007, Nosrati et al. 2007, Bartkowska 2012]. At most plants the process is limited to the temperature of $55 \div 60{ }^{\circ} \mathrm{C}$, which offers the possibility of recovering the surplus heat. High temperature and decreased overall dimensions of reactor (computational time of retention 
is a few days) allow significant reduction of organic substances to the level of $38 \div 50 \%$ VS (volatile solids) [Layden 2007, Bartkowska 2015], and safe sludge concerning the content of pathogenic microorganisms.

During the process the thermophilic population of microorganisms replaces the raw sludge organisms. It is a homogenous microflora, which consists of the Bacillus, Thermus or Actiomycestes bacteria in more than 95\% [Lasik and Nowak 2006, Kovács et al. 2007]. Most strains belong to the Bacillusstearothermophilus specoes, which is active within the termpartures $40 \div 80{ }^{\circ} \mathrm{C}$. The remaining microflora is made up of thermo tolerant mesophilic bacteria, and the extremely thermophoilic bacteria, such as Thermus [Pietrina et al. 2010a, 2010b]. They are characterized by the ability to proliferate at quick rate and rapidly atrophy undergoing autolysis. As they develop, a typical phase of endogenic respiration cannot be observed. However, the produced actively intra-cellular thermo stable hydrolytic enzymes are capable of quick and effective hydrolysis of proteins, lipids, carbohydrates, and other organic compounds, as well of lysis of necrotic cells of numerous microorganisms (e.g. pathogenic bacteria, yeasts, or eggs of intestinal parasites). Fatty acids stemming from hydrolytic products are the chief source of carbon and energy for thermophilic bacteria, although amino acids are the main source of nitrogen. Moreover, these bacteria are characterized by high resistance to metabolic products and by the ability to accommodate to scarcity of oxygen. Rapid growth of thermophilic bacteria, without the necessity of inoculating sludge with proper microflora, quick biodegradation of substrate, small sensitivity to temperature changes, and residence to periodic pauses in aeration of the system guarantee, even in break-down situations an unusually stable and flexible biological system in the environment of thermophilic aerobic stabilization [Lasik and Nowak 2006].

Unfortunately, the side-effect of the process of thermophilic aerobic digestion is strong foam formation and odorous burden. Foaming appears as the thermophilic bacterial population grows. Atrophic cells of these microorganisms release intra-cellular matter, which causes lowering of the surface tension contributing to the formation of great amount of foam. Foaming means the process runs correctly. Moreover, it makes good in- sulation and ensures better use of the atmospheric oxygen. Just within the foam biological activity is at its peak. However, for operating purposes foam formation should be monitored, especially its thickness and, in a sense, the density of the formed foam layer.

The air carried off the chambers of thermophilic aerobic digestion contains compounds, which must be considered odorously burdensome. These are ammonia in the first place, and the products of decay and of imperfect oxidation of organic substances. Ammonia forms as a result of protein ammonification and is the main causer of the odorous burden of the process. Beside ammonia there are reduced sulfur compounds (e.g. hydrogen sulfide, mercaptanes, dimethyl sulfide), aldehydes, ketones, volatile fatty acids, thioalcohols, and others [Bartkowska et al. 2007a, 2007b].

Excess sludge preliminarily thickened is fed into two thermophilic aerobic stabilization reactors, working as a series system. At the first stage of installation the temperature stays at the lower range of thermophilic decay $\left(40 \div 50^{\circ} \mathrm{C}\right)$. Maximal disinfection is achieved at the last stage, where the temperature oscillates between 50 and 60 degrees Celsius [Augustin et al. 2007]. Daily dump of neutralized sludge takes place only from the last stage. When next dump is finished, raw sludge is fed to the first stage, while partially processed sludge is moved to the next reactor. The movement of sludge from one reactor to another causes only little temperature drop. After haven been fed with sludge the reactors stay insulated for 23 hours, when the thermophilic decay is effected [Bartkowska 2005, Bartkowska and Dzienins 2007]. To limit the temperature rise a heat-exchanger is installed in the final reactor.

The examined installation consists of two reactors made as steel tanks, round, of enamel sheet, insulated with a layer of mineral wool 10 $\mathrm{mm}$ thick, coated with sheet aluminum. A single tank diameter is $7.71 \mathrm{~m}$, its total height $3.60 \mathrm{~m}$. Sludge filing is $2.80 \mathrm{~m}$ what creates a functional capacity of $130 \mathrm{~m}^{3}$. The basic technological equipment of each reactor consists of: central aerator, spiral aerators (two pieces), foam breakers (4 pieces), tubular-plate exchanger (only in the second reactor), temperature sensor (2 pieces), hydrostatic level sensor, and cut-off fittings [Bartkowska 2013b, 2014b]. A diagram of sludge center is shown in Figure 1. 


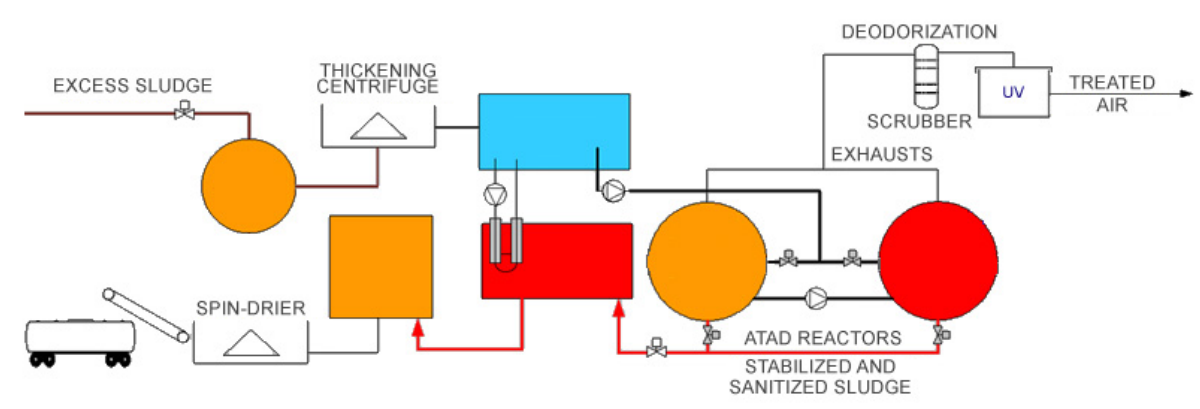

Figure 1. Diagram of the examined sludge center of sewage-treatment plant

\section{MATERIALS AND METHODS}

\section{Sewage sludge}

The subject of the study was sludge from a municipal sewage treatment plant. This sewage treatment plant purifies wastewater from a town in the north-eastern part of Poland. This town is a district town and as well a significant centre of vacation and recreation centre. Apart from a typical household sewage the wastewater sewage treatment plant receives also industrial sewage from a local dairy and pork-butchers shop with their portion in the total volume of sewage being around $17 \%$. The sewage is treated in 5 bioreactors of the SBR type. With the technological system it is possible to support removal of phosphor compounds by precipitating them with iron sulphate, however, using this process during the study was not necessary. The average full-day volume of purified sewage was approximate 3600 $\mathrm{m}^{3}$. In biological chambers generates excessive sludge, which is only in part stabilised. The average stabilisation time of the sludge in working chambers was 8 days. The average $24 \mathrm{~h}$ volume of discharged sludge was $110 \mathrm{~m}^{3}$. The sludge is carried away to a thickener or a retention tank. During sludge densification no polyelectrolytes were used.

The thickened sewage sludge is transferred to ATSO reactors. Table 1 presents average parameter values of the process-purified thickened sludge as determined during the study. The temperature of the thickened sludge during the analysed period was $10-25^{\circ} \mathrm{C}$.

Microbiological examinations were carried out in an accredited laboratory of the Province Environmental Protection Inspectorate in Bialystok and the typical presence of microflora and microfauna for the active sludge was confirmed. The quality composition of the sludge is presented in Table 2.

\section{Sampling and analysis}

The study was carried out at an actual facility in 2012 and 2013. Two study cycles were performed - 18 weeks each. The examination was made on the sludge taken from the thickener and both ATSO reactors. A representative sample for the study was received by way of sampling, combining and mixing at least 10 samples from the same facility and the same time according to polish standard PN-EN ISO 5667-13:2004 (N). Table 3 presents methods used for the study.

Testing reference methods of municipal sewage sludge as indicated in the Ordinance of the Ministry of Environment of July 13, 2010 on municipal sewage sludge were applied.

In order to eliminate errors every determination was repeated three times. The mean from three

Table 1. Properties of sewage sludge received by ATSO reactors

\begin{tabular}{|l|c|c|}
\hline \multicolumn{1}{|c|}{ Parameter } & Unit & Mean value \\
\hline Dry mass & $\mathrm{g} / \mathrm{l}$ & 98.15 \\
\hline Organic dry mass & $\mathrm{g} / \mathrm{l}$ & 72.58 \\
\hline $\begin{array}{l}\text { Chemical oxygen demand } \\
\text { (ChZT) }\end{array}$ & $\mathrm{g} \mathrm{O}_{2} / \mathrm{l}$ & 205.43 \\
\hline Reaction & $\mathrm{pH}$ & 6.2 \\
\hline
\end{tabular}

Table 2. Microscopic evaluation of the thickened sludge

\begin{tabular}{|l|c|}
\hline Rhizopoda (Rhizopoda) & very numerous \\
\hline Mostigopharan (Flagellata) & very numerous \\
\hline Free floating infusorian (Ciliata) & fairly numerous \\
\hline Amoeba (Amoeba) & fairly numerous \\
\hline Rotifier (Rotatoria) & sporadically \\
\hline Sedative infusorian (infusoria) & sporadically \\
\hline Crawling infusorian & sporadically \\
\hline $\begin{array}{l}\text { Different kinds of dispersed } \\
\text { bacteria }\end{array}$ & massively \\
\hline
\end{tabular}

Determinations were made to polish standards. 
Table 3. Methods for the study of sludge

\begin{tabular}{|l|l|c|}
\hline Parametr & \multicolumn{1}{|c|}{ Test metod } & According to: \\
\hline Dry mass & $\begin{array}{l}\text { By weight, drying at } \\
105^{\circ} \mathrm{C}\end{array}$ & PN-EN 12880:2004 \\
\hline $\begin{array}{l}\text { Organic dry } \\
\text { mass }\end{array}$ & $\begin{array}{l}\text { By weight, roasting at } \\
600^{\circ} \mathrm{C}\end{array}$ & PN-EN 12879:2004 \\
\hline ChZT & Spectrophotographic & PN-ISO 15705:2005 \\
\hline
\end{tabular}

simultaneously carried out determinations was adopted for the final analysis of the study results.

The $\mathrm{pH}$ and temperature measurements were carried out during in situ testing at selected facilities (sludge thickener, ATSO reactor 1 and ATSO reactor 2). For the study a multi-parameter meter HQD Hach Lange was used. This meter is provided with two measuring channels for electrodes and a data memory for 500 results. INTELLICAL electrodes in a watertight encasing of stainless steel and reinforced with a cable $30 \mathrm{~m}$ long were used. The calibration data are saved in the electrode. The meter recognizes the electrode automatically and verifies the calibration update. Essential technical data of this meter are presented in Table 4.

With electrodes measurements of $\mathrm{pH}$, conductivity and temperature were conducted directly in the thickener and ATSO reactors. Every parameter was recorded daily at the same day time at intervals several minutes at least ten times.

\section{RESULTS AND DISCUSSION}

During the process of ATSO changes to parameters under study were observed. The level of the sludge dry mass, organic substances or the reaction was changing gradually. The mean values of examined parameters in the first and second stage reactor are given in Table 5 .

Within the period of study in up to $90 \%$ of cases of observation the sludge temperature in the first reactor were 42 to $56^{\circ} \mathrm{C}$. In the second stage reactor higher temperatures were recorded: $59-65^{\circ} \mathrm{C}$.

The drop in the organic mass portion after the first stage of ATSO installation was 33-37\%.
After the second installation stage the dry mass content dropped further by $10-12 \%$.

Basing on continuous measurement of the sludge temperature it was noted that the sludge temperature increased spontaneously by $30-33^{\circ} \mathrm{C}$. In the second reactor the temperature increase was smaller: by successive $8-10^{\circ} \mathrm{C}$.

During the ATSO process the $\mathrm{pH}$ value rose by 1.2 up to 1.5 units in the first tank and by successive $0.6-0.8$ units in the second tank. Similar $\mathrm{pH}$ changes in the sludge were also observed in [Bartkowska 2014a].

Results of the sludge conductivity during its ATSO process stabilisation were subject to a detailed analysis. Results of the thickened sludge study after the first installation stage and of the stabilised sludge were analysed clear-sightedly. To interpret the results methods of a descriptive stats were applied. Calculations were carried out with the STATISTICA software. Statistical distributions of a studied feature are show in Figure 2.

As seen in the figure, the graph representing the results of studies of thickened sludge is right-hand asymmetric. Other distributions of the results of the examined conductivity in first and second-stage reactors are symmetric.

The results were statistically analyzed. Summation of the data set, to draw basic collusions and make generalizations, was made with use of descriptive statistics and regression analysis. The results are shown in Table 6.

On the basis of result analysis a significant increase of conductivity of stabilized sludge can be seen. The mean value of conductivity of thickened sludge was $2192.28 \mu \mathrm{S} / \mathrm{cm}$ in the examination period. The results varied from a minimum

Table 5. Average values of parameters under study

\begin{tabular}{|l|c|c|c|}
\hline Parameter & Unit & $\begin{array}{c}\text { First stage } \\
\text { reactor }\end{array}$ & $\begin{array}{c}\text { Second } \\
\text { stage reactor }\end{array}$ \\
\hline Dry mass & $\mathrm{g} / \mathrm{l}$ & 68.79 & 57.48 \\
\hline $\begin{array}{l}\text { Dry organic } \\
\text { mass }\end{array}$ & $\mathrm{g} / \mathrm{l}$ & 46.57 & 39.12 \\
\hline Chzt & $\mathrm{g} \mathrm{O}_{2} / \mathrm{l}$ & 131.36 & 108.91 \\
\hline Reaction & $\mathrm{pH}$ & 7.5 & 8.7 \\
\hline
\end{tabular}

Table 4. Technical data of the HQD multi-parameter meter

\begin{tabular}{|l|c|c|c|}
\hline \multicolumn{1}{|c|}{ Parameter } & Measuring scope & Resolving power & Accuraccy \\
\hline $\mathrm{pH}$ & $0-14$ & $0.1 / 0.01 / 0.001$ & \pm 0.002 \\
\hline Conductivity & up to $200 \mathrm{mS} / \mathrm{cm}$ & $0.1 / 0.01 / 0.001$ & $\pm 0.001 \mathrm{mS} / \mathrm{cm}$ \\
\hline Temperature & $-10^{\circ} \mathrm{C}-100^{\circ} \mathrm{C}$ & $0.1^{\circ} \mathrm{C}$ & $\pm 0.3^{\circ} \mathrm{C}$ \\
\hline
\end{tabular}




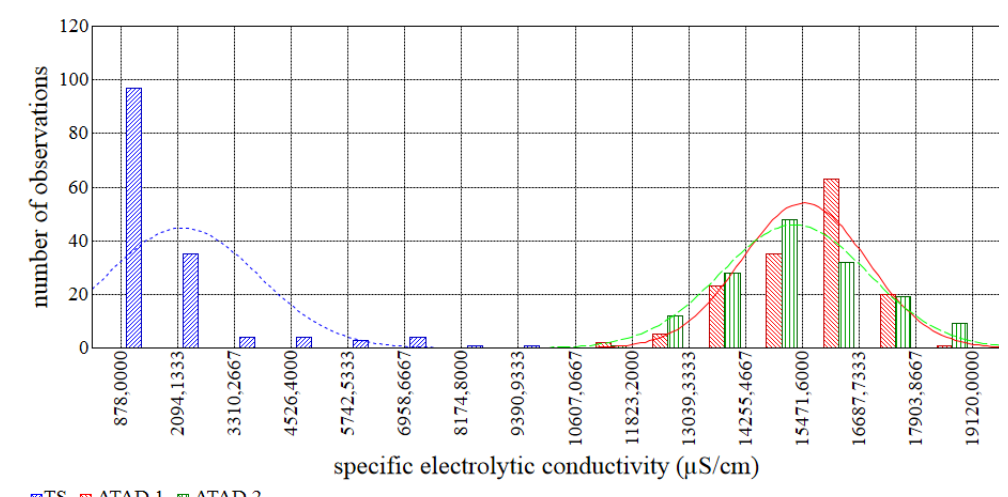

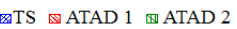

Figure 2. Graphic representation of distribution of the studied parameter

Table 6. Values of selected distribution measures

\begin{tabular}{|l|c|c|c|}
\hline \multirow{2}{*}{\multicolumn{1}{|c}{ Measures of distribution }} & \multicolumn{3}{|c|}{ Conductivity of sludge $(\mu \mathrm{s} / \mathrm{cm})$} \\
\cline { 2 - 4 } & \multirow{2}{*}{ Thickened } & In reactor \\
\cline { 2 - 4 } & & 10810.00 & 11420.00 \\
\hline Minimum value & 878.00 & 18390.00 & 19120.00 \\
\hline Maximum value & 9880.00 & 15429.16 & 15222.00 \\
\hline Arithmetic mean & 2192.28 & 15680.00 & 15270.00 \\
\hline Median & 1652.00 & multiple & 14830.00 \\
\hline Mode & multiple & 1336.54 & 1572.98 \\
\hline Standard deviation & 1614.63 & 1786345.00 & 2474276.00 \\
\hline Variation & 2607022.00 & -0.64 & 0.12 \\
\hline Skewness coefficient & 2.62 & 0.44 & -0.24 \\
\hline Kurtosis & 7.12 & 13710.00 & 13290.00 \\
\hline Percentile 10\% & 1085.00 & 16830.00 & 17400.00 \\
\hline Percentile 90\% & 4450.00 & & \\
\hline
\end{tabular}

value $878.00 \mu \mathrm{S} / \mathrm{cm}$ to maximum value 9880.00 $\mu \mathrm{S} / \mathrm{cm}$. The processed sludge, at the first stage of ATAD, had mean conductivity $15429.16 \mu \mathrm{S} / \mathrm{cm}$, which ranged from $10810.00 \mu \mathrm{S} / \mathrm{cm}$ to 18390.00 $\mu \mathrm{S} / \mathrm{cm}$. Stabilized sludge, within the analyzed time frame, had lower conductivity whose mean value was $15222.00 \mu \mathrm{S} / \mathrm{cm}$. The conductivity range of this sludge oscillated between 11420.00 $\mu \mathrm{S} / \mathrm{cm}$ and $19120.00 \mu \mathrm{S} / \mathrm{cm}$. Significant diversification of results was demonstrated, what is proved by the value of standard deviation and variation, especially in relation to condensed sludge. Conductivity ranges of examined sludge are shown in Figure 3.

The above graph shows how much the sludge conductivity changes during the process of aerobic stabilization. Also, the value of median rises, above and below of which the number of observations is the same. For thickened sludge its value is $1652.00 \mu \mathrm{S} / \mathrm{cm}$, for sludge at the first stage of ATAD installation the value is $15680.00 \mu \mathrm{S} / \mathrm{cm}$, for stabilized sludge it is $15270.00 \mu \mathrm{S} / \mathrm{cm}$. The analyzed distributions are not ideally symmetri- cal. Ninety per cent of study results of thickened sludge has a value lesser than $4450.00 \mu \mathrm{S} / \mathrm{cm}$, sludge after first stage of ATAD installation has the value higher than $13710.00 \mu \mathrm{S} / \mathrm{cm}$, stabilized sludge value exceeds $13290.00 \mu \mathrm{S} / \mathrm{cm}$.

Analysis of regression was also made to demonstrate the relationship between the rise of values of electrolytic conductivity and the changes of the other studied parameters. Necessary calculations were made which let the regression equations be used for results prognosis. The principles of the model were correctly verified. Parameterization made it possible to claim that the assumed quality predictors were determined as statistically significant. However, the value of the coefficient of determination explains the enhanced conductivity of sludge resulting from the ATAD process as an effect of reduction of dry mass and increased reaction at 20 per cent level. It can be agreed on then, that one fifth of the conductivity rise is caused by the mentioned parameters.

During the process of autothermal thermophylic aerobic digestion of sludge the electrolytic 


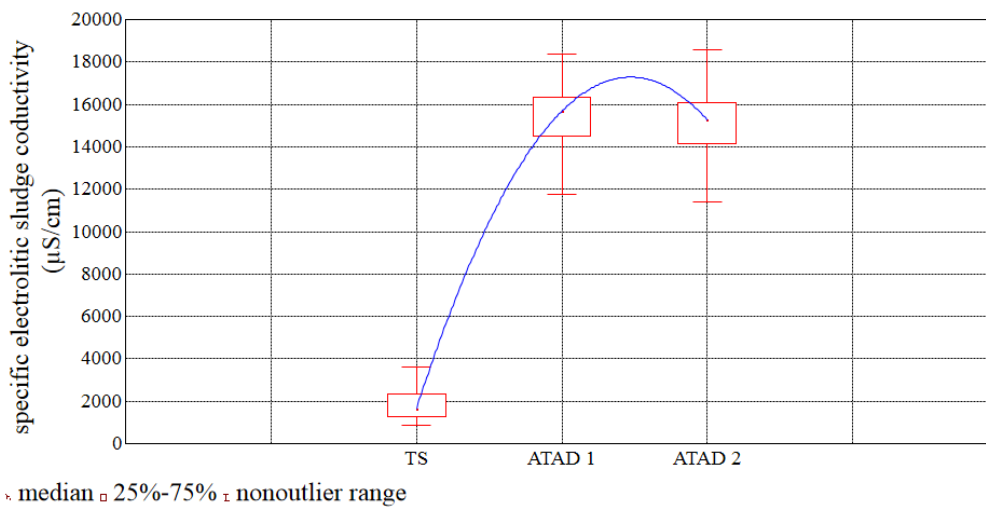

Figure 3. Ranges of electrolytic conductivity of sludge at the time of its stabilization

conductivity increased several times. Continuous measurement of conductivity in reactors showed oscillations, on the basis of which it is difficult to predict the direction of final changes. Small decrease of conductivity in the second-stage reactor is connected with transformation of ions into compounds which do not dissociate. This process is facilitated by higher reaction of studied sludge. The available literature does not contain notes referring to the values of conductivity of sludge or to options how this index might be applied.

During the ATAD process organic matter is oxidated. Measurement of electrolytic conductivity should demonstrate the occurring changes. Electrolytic conductivity mostly depends on the type and amount of dissociated dissolved substances of inorganic character. Such measurements are commonly used to test the degree of general mineralization of water and soil.

\section{CONCLUSIONS}

Autothermal thermophilic aerobic digestion of sludge is a process which ensures its sanitation and effective stabilization [Augustin et al. 2007, Bartkowska et al. 2005a, Bartkowska and Dzienis 2006, 2009, Bartkowska and Wawrentowicz 2011, Bartkowska 2015]. Full automation of the process makes it possible to render sludge which is free of bacteriological contamination and makes a worthy manure which can be successfully returned to the environment [Bartkowska 2013a]. This process is characterized by stable biochemical reactions and short computation time of retained sludge. The installation requires small area, which lowers the cost of investment. The presented technology enables preparation of sludge for its natural application, which re- mains a reasonable manner of its utilization, and improves the balance of organic matter in soil [Bartkowska 2013a].

The electrolytic conductivity is a parameter widely used to examine the quality of superficial and underground waters. Cheap and simple measurement makes it possible to determine the amount of dissociated dissolved substances of inorganic character. Thus it should be helpful when it comes to determination of the degree of mineralization of sludge and deliver the sewage-treatment plant operator essential information about the process of its stabilization. Through monitoring the conductivity of sludge in ATAD reactors we quickly obtain information which lets us control the process and react properly.

The results of studies during the here described period and rich experience stemming from observations of other ATAD installations enable formulation of the following conclusions. First of all, the greatest rise of electrolytic conductivity was observed at the first stage of ATAD installation. Therefore, one should consider the option of increasing the cubature of the first installations stage, which should improve the energetic balance of the process. The sludge in the first-stage reactor heated up faster reaching higher temperature. Increased capacity will make it also possible to feed more air, accordingly to demand.

Furthermore, at the second stage of installation a decrease of processed sludge conductivity was observed. It was most likely caused by transformation of ions into compounds which do not dissociate.

Moreover, on-line measurement of conductivity facilitates the control of the process and offers the opportunity of quick reaction in a case of irregularities. 
The presented technology makes it possible to employ a cheap source of organic matter for natural application and to reduce the amount of waste material produced by a plant. The control of installation work through on-line measurements is safe and rationalizes the work of the personnel of sewage-treatment plant. The carried-out studies let us think that measurement of the conductivity of sludge may bring about rational benefits.

\section{Acknowledgments}

The study was realized during scientific project No. S/WBiIS/02/2014 supported by Polish Ministry of Science and Higher Education.

\section{REFERENCES}

1. Augustin O., Bartkowska I., Dzienis L. 2007. Efficiency of wastewater sludge disinfection by autoheated thermophilic aerobic digestion (ATAD). W: IWA Specialist Conference: Moving Forward : Wasterwater Biosolids Sustainability: technical, managerial and public synergy : conference proceedings, Moncton, Canada, June 24-27, 1037-1043.

2. Bartkowska I. 2005. Operation's initial period of the autothermal thermophilic sludge instalation (ATAD) in Giżycko waste water treatment plant. Polish Journal of Natural Sciences, 18 (1), 105-116.

3. Bartkowska I. 2012. Analysis of temperature change and dry matter content in the process of sludge neutralization. Baltic Coastal Zone, 16, 5-18.

4. Bartkowska I. 2013a. Sludge as an agent improving soil properties. Journal of Ecological Engineering, 14(2), 63-67. doi: 10.5604/2081139X.1043186.

5. Bartkowska I. 2013b. Possible use of selected technological parameters for evaluation of kinetics of auto thermal termophilic stabilizations of wastewater sludge. Monografia, Oficyna Wydawnicza Politechniki Białostockiej. s. 130 (in Polish).

6. Bartkowska I. 2014a. Changes hydrogen ion exponent of sewage sludge-in the process of autothermal thermophilic aerobic digestion. Journal of Ecological Engineering, 15(1), 32-37. doi: $10.12911 / 22998993.1084175$.

7. Bartkowska, I. 2014b. Influence of the sewage sludge stabilisation process on the value of its oxidation reduction potential. Environmental Technology, 35(17), 2160-2166. doi: $10.1080 / 09593330.2014 .895052$.

8. Bartkowska I. 2015. Drop in dry mass and organic substance content in the process of autothermal thermophilic aerobic digestion. Process Safety and Environmental Protection, 98, 170-175. doi: 10.1016/j.psep.2015.07.003.

9. Bartkowska I., Augustin O., Dzienis L. 2005a. Efficiency Of Wastewater Sludge Disinfection By Autoheated Thermophilic Aerobic Digestion. Monografie, Polska Akademia Nauk, Komitet Inżynierii Środowiska, 30, 763-774 (in Polish).

10. Bartkowska I., Augustin, O., Dzienis, L. 2005 b. Use of autothermal aerobic sludge stalilization for the disposal of wast water treatment plants and paper indrustry. Polska Akademia Nauk, Komitet Inżynierii Środowiska, 32, 1025-1033 (in Polish).

11. Bartkowska I., Dzienis L. 2006. Evaluation of the course of autothermal aerobic sludge stabilization on the example of wastewater treatment plant in Giżycko. Materiały Konferencji Naukowo-Technicznej „Postęp w Inżynierii Środowiska”, Politechnika Rzeszowska Baligród, 151-160 (in Polish).

12. Bartkowska I., Dzienis L., 2007. Technical and economic aspects of autothermal thermophilic aerobic digestion exemplified by sewage treatment plant in Giżycko. Environment Protection Engineering, 33(2), 17-25.

13. Bartkowska I., Dzienis L. 2009. Assessment of Operating Efficiency of Autoheated Thermophilic Aerobic Digestion (ATAD) In Two- and ThreeStage Configurations. Polish Journal of Environmental Studies, 6, 11-16.

14. Bartkowska I., Dzienis L., Augustin O. 2007 a. Odour control by photo catalytic ionization. W: IWA Specialist Conference : Moving Forward : Wasterwater Biosolids Sustainability: technical, managerial and public synergy : conference proceedings, Moncton, Canada, June 24-27. 2007.

15. Bartkowska I., Dzienis L., Augustin O. $2007 \mathrm{~b}$. Odor purification in sewage management object with application of photocatalytic oxidation. Polish Journal of Environmental Studies, 16 (2 A), Part III, 461-466.

16. Bartkowska I., Wawrentowicz D. 2011. Efficiency analysis of sewage sludge treatment by means of autoheated thermophilic aerobic digestion (ATAD) on the example of wastewater treatment plant i Giżycko. Inżynieria Ekologiczna, 25, 165-175 (in Polish).

17. Kelly H.G. 2006. Emerging processes in biosolids treatment. J. Environ. Eng. Sci., 5, 175-186.

18. Lasik M., Nowak J. 2006. Thermophilic aerobic biodegradation of food industry wastewater. Biotechnologia, 3 (74) 98-112 (in Polish).

19. Kovács R., Miháltz P., Csikor S. 2007. Supplementation of Wastewater Process Modelling Tools to Enable the Kinetic Analysis of Sewage Sludge Composting. Polish Journal of Environmental Studies, 16(6), 831-839.

20. Layden N.M. 2007. An evaluation of autothermal 
thermophilic aerobic digestion (ATAD) of municipal sludge in Ireland. J. Environ. Eng. Sci., 6, 19-29.

21. Merrington G., Oliver I., Smernik R.J., Mcla Ughlin M.J. 2003. The influence of sewage sludge properties on sludge - borne metal availability. Advances in Environmental Research 8(1), 21-36.

22. Nosrati M., Sreekrishnan T.R., Mukhopadhyay S.N. 2007. Energy Audit, Solids Reduction, and Pathogen Inactivation in Secondary Sludges during Batch Thermophilic Aerobic Digestion Process. Journal of Environmental Engineering, 133 (5), 477-484. doi: 10.1061/(ASCE)0733-9372(20 07)133:5(477).

23. Piterina A.V., Bartlett J., Pembroke T.J. 2010a. Evaluation of the Removal of Indicator Bacteria from Domestic Sludge Processed by Autothermal Thermophilic Aerobic Digestion (ATAD). Int. J. Environ. Res. Public Health., 7(9), 3422-3441. doi: 10.3390/ijerph7093422.
24. Piterina A.V., Bartlett J., Pembroke T.J. 2010b. Molecular Analysis of Bacterial Community DNA in Sludge Undergoing Autothermal Thermophilic Aerobic Digestion (ATAD): Pitfalls and Improved Methodology to Enhance, Diversity Recovery, (2), 505-526. doi: 10.3390/d2040505.

25. Wersocki S., Hupka J. 2006. Autothermal aerobic hygienisation of excess sludge. Inżynieria ekologiczna, 14, $63-69$ (in Polish).

26. Zhou J., Mavinic D.S., Kelly H.G., Ramey W.D. 2002. Dewaterability of thermophilically digested biosolids: effects of temperature and cellular polymeric substances. CSCE/ASCE-EWRI Environmental Engineering Conference, Niagara Falls, Canada.

27. Zupančič G.D., Roš, M. 2008. Aerobic and twostage anaerobic-aerobic sludge digestion with pure oxygen and air aeration. Bioresource Technology, 99, 100-109. doi: 10.1016/j.biortech.2006.11.054. 